\title{
Bisalbuminaemia in pancreatic ascites
}

\author{
S. Keidar ${ }^{1}$, L. Hornstein ${ }^{2}$ and J.G. Brook ${ }^{1}$ \\ ${ }^{1}$ Department of Internal Medicine D, Rambam Medical Center and Faculty of Medicine, Technion-Israel Institute \\ of Technology, Haifa and ${ }^{2}$ Department of Immunology, Lady Davis Carmel Hospital, Haifa, Israel
}

\begin{abstract}
Summary: A patient with pancreatic ascites is described. Electrophoresis of the patient's serum demonstrated bisalbuminaemia, which disappeared after resolution of the ascites.
\end{abstract}

\section{Introduction}

Bisalbuminaemia is a rarely occurring and even more rarely described condition. The diagnosis is based on the appearance, on blood protein electrophoresis, of an unusually broad band, or of two distinct components, representing albumin. The extra component may exhibit either fast or slow electrophoretic mobility.

Three classes of bisalbuminaemia have been described: (1) Hereditary types of variant molecules (which may be fast, slow or neither and are unassociated with disease) (Le Treut et al., 1977), (2) a transient phenomenon due to a ligand (e.g. penicillin) altering the electrophoretic mobility of normal albumin while it is bound to it (Arvan et al., 1968; Keidar et al., 1981); and (3) normal albumin chains shortened by pancreatic enzyme action (Donowitz et al., 1974; Rousseaux et al., 1976).

In this report a case of acquired transient bisalbuminaemia occurring in a patient with pancreatic ascites is described.

\section{Case report}

A 50 year old man was admitted because of a 3-week history of weight loss, abdominal pain and marked abdominal swelling. There was a past history of alcohol abuse. The liver was palpable $2 \mathrm{~cm}$ below the costal margin; the spleen was not enlarged and there was shifting dullness, indicative of considerable ascites.

Laboratory tests showed normal liver function apart from a total protein of $5.5 \mathrm{~g} / \mathrm{l}$, albumin $3.0 \mathrm{~g} / 1$ and globulin $2.5 \mathrm{~g} / \mathrm{l}$. The two main abnormalities were a high serum amylase (3130 Somogyi $\mathrm{U} / \mathrm{dl}$ ) and a fast type of albumin on cellulose actetate serum electro-

Correspondence: J.G. Brook, M.D., Department of Internal Medicine D, Rambam Medical Center, POB 9602, Haifa 31096, Israel.

Accepted: 31 July 1985 phoresis (Figure 1). A diagnostic abdominal paracentesis yielded a straw-coloured fluid which proved to be sterile on culture, and cytological studies showed no malignant cells. The albumin content was $4.2 \mathrm{~g} / \mathrm{l}$ and the amylase level was 2800 Somogyi U/dl. X-ray studies, including barium meal, barium enema, oral cholecystography and computed tomography of the pancreatic area, were normal. A liver scan showed a slightly enlarged but homogeneous liver.

Despite conservative treatment, the patient did not improve. An endoscopic retrograde pancreatogram (ERCP) was performed. The procedure demonstrated only the proximal part of the main pancreatic duct, which was somewhat narrow but otherwise of normal configuration. No pancreatic duct leakage or pseudocyst was observed. Shortly after completion of the test, the patient complained of severe abdominal pain, associated with profuse perspiration and the appearance of leucocytosis and further elevation of the serum amylase. Conservative therapy was continued, and after 10 days a gradual improvement became

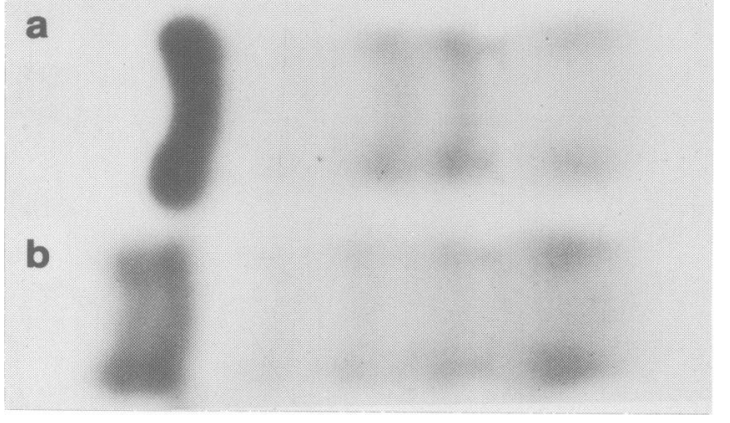

Figure 1 Protein electrophoresis of serum, $\mathrm{pH} 8.6$. (a) Control; (b) Patient's serum. Note fast-moving band in the patient's serum which is consistent with the presence of bisalbuminaemia.

(C) The Fellowship of Postgraduate Medicine, 1986 
obvious. The ascites decreased and was undetectable after 3 weeks. The serum amylase returned gradually to normal. The bisalbuminaemia disappeared after 6 months and during a 4 year follow-up, the patient has remained asymptomatic.

\section{Discussion}

The patient described in our report suffered from chronic pancreatic disease, probably of alcoholic aetiology. Ascites was detected on admission and was diagnosed as pancreatic ascites, due to the high albumin (over $3.9 \mathrm{~g} / \mathrm{l}$ ) and high amylase level in both ascitic fluid and serum (Shashaty \& Atmer, 1972). As the patient had not been treated with high doses of antibiotics, the transient bisalbuminaemia that was observed on serum protein electrophoresis may be the result of the presence of pancreatic ascites. Indeed, Rousseaux et al. (1976) have pointed out that this fast albumin is produced by the degradation of normal

\section{References}

ARVAN, D., BLUMBERG, B. \& MELARTIN, C. (1968). Transient bisalbuminaemia induced by drugs. Clinica Chimica Acta, 22, 211.

DONOWITZ, M., KERSTEIN, M.D. \& SPIRO, M.M. (1974). Pancreatic ascites. Medicine, 53, 183.

KEIDAR, S., HORENSTEIN, L., HEFTER, F. \& LAVIE, L. (1981). Bisalbuminaemia in patients receiving high doses of penicillin. Harefuah, 101, 300.

LE TREUT, A., CATHELINE, M. \& ClOAREC, L. (1977). Bisalbuminémie héréditaire et familiale. Bisalbuminémie serum albumin by the proteolytic enzymes of the pancreas. Structural analysis of this isolated fas albumin shows that the terminal end of the molecule different from normal serum albumin, and this results from limited degradation by the enzymes of the pancreas.

The pancreatic ascites in our patient must ha resulted from a leakage secondary to a disruption the pancreatic duct. The patient developed acufe pancreatitis soon after the ERCP. Subsequently, the ascites subsided, and it is likely that the inflammato process sealed the leakage and this 'cured' the pan. creatic ascites.

The appearance of bisalbuminaemia is probabtr commoner than realized, and often ignored whe found. It should therefore always be followed by further investigation, in order to determine the type of bisalbumin found, and its cause. Should it be causq by drugs or by pancreatic disease, the patient should then receive the appropriate treatment.

acquise et transitoire. Pathologie-Biologie, 25, 47. ROUSSEAUX, J., DEBEAMONT, D., SCHARFMAN, A., POMMELET, P., DAUTREVAUX, M. \& BISERTE, G. (18 $\overrightarrow{6 \vec{b}}$ Bisalbuminaemia in pancreatitis; structural modific of human serum albumin by proteolytic enzymes ofthe pancreas. Clinica Chimica Acta, 71, 35.

SHASHATY, G. \& ATMER, M. (1972). Acquired bisalbumi aemia with hyperamylasaemia. American Journal of Dige tive Diseases, 17, 59. 